Research Article

\title{
Immunomodulatory effects of fruits of Barringtonia racemosa Linn.
}

\author{
Prabhakar R. Patil ${ }^{\text {**, }}$,Mahesh R. Patil ${ }^{\mathrm{b}}$, Abhay Mane ${ }^{\mathrm{a}}$, Sudha Patil ${ }^{\mathrm{a}}$
}

${ }^{a}$ Department of Pharmacology, Navodaya Medical College, Raichur, Karnataka, India, ${ }^{\mathrm{b}}$ R.C. Patel College of Pharmacy, Shirpur, Dist. - Dhule, Maharashtra, India

Received: 30 January 2013

Accepted: 11 February 2013

*Correspondence to:

Dr. Prabhakar R. Patil,

Email: drprpati12006@gmail.com

(C) 2013 Patil PR et al. This is an open-access article distributed under the terms of the Creative Commons Attribution License, which permits unrestricted use, distribution, and reproduction in any medium, provided the original work is properly cited.

\begin{abstract}
Background: Barringtonia racemosa (B. racemosa) is used medicinally in treatment of diarrhoea, asthma, coughs, jaundice. It is also used as an analgesic and antipyretic. This plant has also significant anti-tumor activity. However, systematic evaluation of its immunomodulatory effects has not been reported. In present study the hydroalcoholic extract of fruits of $B$. racemosa has been evaluated for its immunomodulatory properties in animal models.

Methods: Extract of Fruits of B. racemosa was prepared from fruit powder and methanol by macerations and filtration. Healthy albino Wistar rats of either sex having 110-160 g body weight were used for this study. 1. Delayed type hypersensitivity reaction (DTH) using Sheep red blood cells (SRBCs): After immunization with SRBC effect of cyclophosphamide and hydroalcoholic extract of $B$. racemosa was seen on paw volume changes in rats challenged with SRBC by using digital Plethysmometer. 2. Humoral antibody response to SRBC: Animas were immunized with SRBC and treated with cyclophosphamide and hydroalcoholic extract of B. racemosa. Serum of these animals was observed for haemagglutination titer.

Results: Fruits extract at the dose of $5 \mathrm{mg} / \mathrm{kg}$ i.p. showed significant decrease in DTH response as compared to that of control group animals. However, the effect of extract was less potent as compared to that of cyclophosphamide treated group. In haemagglutination titer assay, antibody titer in case naïve control, SRBC treated, cyclophosphamide treated and extract treated groups was $1: 1,1: 32,1: 8$ and $1: 16$ respectively.

Conclusions: The hydroalcoholic extract of this fruits was found to inhibit SRBCs induced DTH in rats. Similarly, SRBCs induced antibody titer was also reduced.
\end{abstract}

Keywords: Barringtonia racemosa, Immunomodulation, Humoral immunity, Cellular immunity

\section{INTRODUCTION}

Barringtonia racemosa (B. racemosa) (familyBarringtoniaceae) is a tall tree with one seeded, ovoid fruits, distributed in eastern and western seacoasts of India. The fruit pulp of $B$. racemosa had been in use as a fish poison. Apart from this, the plant is also used medicinally in treatment of diarrhoea, asthma, coughs, jaundice as well as an analgesic and antipyretic. ${ }^{1,2}$ Some recent reports claim that $B$. racemosa possesses significant anti-tumor activity. ${ }^{3}$ However, systematic evaluation of its immunomodulatory effects has not been reported. In present investigation the hydroalcoholic extract of fruits of $B$. racemosa has been evaluated for its immunomodulatory properties in animal models.

\section{METHODS}

\section{Preparation of extracts}

Fruits of B. racemosa were purchased from a local vendor and were authenticated at Botanical Survey of India, Pune, India. The fruits were coarsely powdered and macerated with methanol: water $(1: 1)$ for 8 hours with frequent stirring. At the end of maceration, the extract was filtered and the filtrate was dried under vacuum in a rotary evaporator under reduced pressure at $40^{\circ} \mathrm{C}-45^{0} \mathrm{C} .^{3}$

\section{Chemicals}


For evaluation of immunomodulatory activity, different standard drugs and chemicals of following specifications were used. Cyclophosphamide (Dabur Pharma, New Delhi, India), Dextran (Molecular weight- 1,00,000 to 1,50,000), Minimum Essential Medium (MEM), casein, Haematoxylin stain, Giemsa's stain, tryptan blue dye (Himedia Labs, Mumbai, India).

\section{Animals used}

Healthy albino Wistar rats of either sex having 110-160 g body weight were used for this study. The rats were housed in polypropylene cages and maintained under standard conditions (12 hrs light and dark cycles, at $25 \pm 3^{\circ} \mathrm{C}$ and $35-60 \%$ humidity). Standard palletized feed and tap water were provided ad libitum. The study was approved by the Institutional Animal Ethical Committee of R.C. Patel College of Pharmacy, Shirpur, India, registered under CPCSEA, India (Registration No. 651/02/C/CPCSEA).

\section{Dosage and concentrations}

Treatment with the fruit extract and standard drugs were given by intraperitoneal route. For preparation of drug solutions sterile pyrogen free saline was used and the solutions were filtered through $0.2 \mu$ filter (Millipore) immediately before administration. As a standard drug, Cyclophosphamide at a dose of $50 \mathrm{mg} / \mathrm{kg}$ body weight, given by intraperitoneal route was used. ${ }^{4,5}$ It was not administered for more than three to four days in any case.

\section{Antigen}

As an antigen, Sheep red blood cells (SRBCs) were used. Fresh sheep blood was collected and aseptically added to sterile Alsever's solution in 1:1 proportion. ${ }^{6}$ Then the SRBCs were washed three times with pyrogen free sterile phosphate buffer saline $(\mathrm{PBS})^{7}$ and the count was adjusted approximately to $0.5 \times 10^{9}$ cells $/ \mathrm{ml}^{8}{ }^{8}$

\section{Delayed type hypersensitivity reaction (DTH) using SRBCS}

Eighteen wistar rats of either sex were divided into three groups consisting of six rats each. On day ' 0 ', animals in all the groups were immunized by intraperitoneal administration of $0.5 \times 10^{9}$ cells / ml/ 100gm of SRBCs suspension. Dosing of the animals as per assigned treatment schedule was started on the same day.

Negative control group received normal saline given by intraperitoneal route from day 0 to day 7 of the experiment; positive control group received no treatment till day 4 of experimentation. To this group, the drug cyclophosphamide $(50 \mathrm{mg} / \mathrm{kg} /$ day; i.p.) was started on day 5 and was continued till day 7 . The extract treated group was administered with hydroalcoholic extract of $B$. racemosa $(5 \mathrm{mg} / \mathrm{kg} /$ day; i. p.) from day 0 to day 7 . This dose of the extract was found to be non toxic in the primary studies carried out in our laboratory (results not included here) and also considering earlier reports on this plant.

On day 7 , all the three groups of rats were challenged with $0.1 \mathrm{ml}$ of $0.5 \times 10^{9}$ cells/ ml SRBCs in left hind foot pad, while contra lateral foot pad was injected with equal volume of normal saline. ${ }^{4}$ The thickness of both foot pads in case of all the animals was measured at 0, 24, 48 hours plethysmometrically using digital Plethysmometer (UgoBasile 7140, Italy). ${ }^{9}$ The difference in the volume of left paws at 0 hour and 48 hours was used as a measure of DTH reaction. ${ }^{10,11}$

\section{Humoral antibody response to $S R B C$}

Twenty four wistar rats of either sex were divided into four groups containing six rats in each. On the day ' 0 ' of experiment, rats in all the groups except naïve control group were immunized by intraperitoneal administration of $0.5 \times 10^{9}$ cells/ ml/ $100 \mathrm{gm}$ of SRBCs. ${ }^{12}$ The rats were administered with the assigned treatments as stated above. To standard drug treated group, Cyclophosphamide at dose of $50 \mathrm{mg} / \mathrm{kg} /$ day (i.p.) was administered on days 5, 6, 7 .

On day 7, blood samples were collected from all treatment groups through retro orbital puncture. ${ }^{5,11}$ Serum was rapidly separated by centrifugation. In ' $\mathrm{V}$ ' bottom 96 well microplates' two fold serial dilutions of $25 \mu \mathrm{l}$ serum samples in saline were prepared. The plates were incubated at $56^{\circ} \mathrm{C}$ for 30 minutes. At the end of the incubation period, $25 \mu \mathrm{l}$ of $1 \% \mathrm{v} / \mathrm{v}$ SRBC suspension was added to each well. The microplates were shaken manually and further incubated at $37^{\circ} \mathrm{C}$ for $1 \mathrm{hr}$. The plates were then visually observed for haemagglutination titer. The minimum dilution showing button formation at the bottom of the well was taken as haemagglutination titer. $^{13,14}$

\section{Statistical analysis}

The data obtained was analyzed for statistical significance using one-way ANOVA followed by Bonferroni's Multiple Comparison test using Graphpad Prism 4.0 software.

\section{RESULTS}

\section{Effect of hydroalcoholic extract on delayed type hypersensitivity reaction (DTH)}

Fruits extract at the dose of $5 \mathrm{mg} / \mathrm{kg}$ i.p. showed significant decrease in DTH response as compared to that of control group animals. The DTH reaction was significantly inhibited in both cyclophosphamide and extract treated animals. However, the effect of extract was less potent as compared to that of cyclophosphamide treated group (Figure 1). 


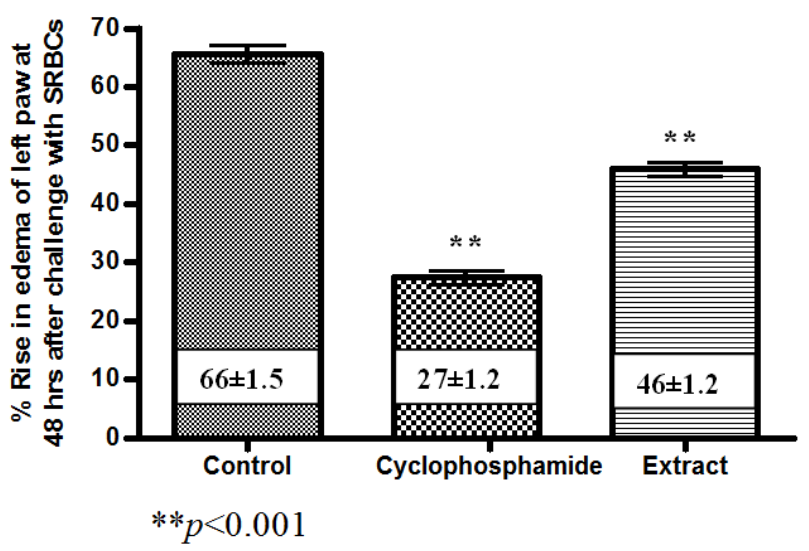

Figure 1: Effect of extract of $B$. racemosa fruits in SRBCs induced DTH.

\section{Effect on humoral antibody}

In haemagglutination titer assay, antibody titer in case naïve control, SRBC treated, cyclophosphamide treated and extract treated groups was 1:1, 1:32, 1:8 and 1:16 respectively. Such decrease in the titer value indicates that hydroalcoholic extract causes suppression of antibody formation against the injected SRBCs (Table 1).

Table 1: Effect of B. racemosa on SRBC induced antibody titer in rats.

\begin{tabular}{|ll|}
\hline Group & Titer \\
\hline Naïve control & $1: 1$ \\
\hline SRBC treated & $1: 32$ \\
\hline SRBC + Cyclophosphamide $(50 \mathrm{mg} / \mathrm{kg})$ & $1: 8$ \\
\hline SRBC + Extract ( $5 \mathrm{mg} / \mathrm{kg})$ & $1: 16$ \\
\hline
\end{tabular}

\section{DISCUSSION}

B. racemosa plant has been reported to possess numerous biological activities like anti-tumor activity and antiasthmatic activity which point towards possible immunomodulatory activity of this plant. In present study, the fruit extract of this plant has been investigated in invivo and in vitro experimental models related to immune system activity.

At the dose of $5 \mathrm{mg} / \mathrm{kg}$, the hydroalcoholic fruit extract of $B$. racemosa significantly reduced the intensity of delayed type hypersensitivity induced by SRBC as antigen. Similarly, SRBC induced antibody titer was significantly reduced. These observations are coherent with its anti-tumor and anti-asthmatic effects. It is proposed that, the extracts of $B$. racemosa studied in present investigation may be further fractionated and investigated using more sensitive in vivo and in vitro models related to immune system disorders.
Funding: No funding sources

Competing interests: No competing interests

Ethical approval: The study was approved by the

Institutional Animal Ethical Committee of R.C. Patel

College of Pharmacy, Shirpur, India

\section{REFERENCES}

1. Khan S, Jabbar A, Hasan CM, Rashid MA. Antibacterial activity of Barringtonia racemosa. J Ethnopharmacol 2001;72:162-4.

2. Deraniyagala SA, Ratnasooriya WD, Goonasekera CL. Antinociceptive effect and toxicological study of the aqueous bark extract of Barringtonia racemosa on rats. J Ethnopharmacol 2003;86:21-6.

3. Thomas TJ, Panikkar B, Subramoniam A, Nair M, Panikkar KR. Antitumor property and toxicity of Barringtonia racemosa roxb seed extract in mice. $\mathrm{J}$ Ethnopharmacol 2002;82:223-7.

4. Makare N, Bodhankar S, Rangari V. Immunomodulatory activity of alcoholic extract of Mangifera indica L. in mice. J Ethnopharmacol 2001;78:133-7.

5. Agarwal R, Diwanay S, Patki P, Patwardhan B. Studies on immunomodulatory activity of Withania somnifera (Ashwagandha) extracts in experimental immune inflammation. J Ethnopharmacol 1999;67:27-35.

6. Moudgil KD, Singh KA. Agglutinaton Methods. In: Talwar GP, Gupta SK, Editors, A Handbook of practical and clinical immunology. Vol-I, $2^{\text {nd }}$ edition, CBS distributors, New Delhi; 1997: p.199.

7. Gupta SK. Production of murine Monoclonal antibodies. In: Talwar GP, Gupta SK, Editors, A Handbook of practical and clinical immunology Vol-I, $2^{\text {nd }}$ edition, CBS distributors, New Delhi; 1997: p. 99.

8. Bin-Hafeez B, Haque R, Parvez S, Pandey S, Sayeed I, Raisuddin S. Immunomodulatory effects of fenugreek (Trigonella foenum graecum L.) extract in mice. Int $\mathbf{J}$ Immunopharmacol 2003;3:257-65.

9. Damre AS, Gokhale AB, Phadke AS, Kulkarni KR, Saraf MN. Studies on the immunomodulatory activity of flavonoidal fraction of Tephrosia purpurea. Fitoterapia 2003;74:257-61.

10. Tiwari U, Rastogi B, Thakur S, Jain S, Saraf DK. Studies on the immunomodulatory effects of Cleome viscose. Indian J Pharm Sci 2004;66:171-6.

11. Mediratta PK, Sharma KK, Singh S. Evaluation of immunomodulatory potential of Ocimum sanctum seed oil and its possible mechanism of action. J Ethnopharmacol 2002;80:15-20.

12. Pallabi DE, Dasgupta SC, Gomes A. Immunopotentiating and immunoprophylactic activities of immune 21, a polyherbal product. Indian J Pharmacol 1998;30:163-8.

13. Shinde UA, Phadke AS, Nair AM, Mungantiwar AA, Dikshit VJ, Saraf MN. Preliminary studies on 
the immunomodulatory activity of Cedrus deodara wood oil. Fitoterapia 1999;70:333-9.

14. Ghazanfari T, Zuhair H, Marzieh E. Immunomodulatory activity of a protein isolated from garlic extract on delayed type hypersensitivity. Int J Immunopharmacol 2002;2:1541-9.

doi:10.5455/2319-2003.ijbcp20130318

Cite this article as: Patil PR, Patil MR, Mane A, Patil

S. Immunomodulatory effects of fruits of Barringtonia racemosa Linn. Int J Basic Clin Pharmacol

2013;2:216-9. 